\title{
UPAYA ISLAMISASI ILMU EKONOMI SEBAGAI SOLUSI MENUJU MASYARAKAT YANG BERKEADILAN
}

\author{
Ahmad Nurcholis
}

\begin{abstract}
ABSTRAK
Keterjebakan Indonesia di dalam hutang luar-negeri tidak terlepas dari hegemonisme dan berkembangnya kapitalisme serta imperialisme baru. Kita melihat bukti yang makin nyata dari hari ke hari terjadinya disempowerment terhadap bangsa dan negara Indonesia. Kita menyaksikan pula bahwa yang terjadi saat ini pembangunan pihak asing di Indonesia dan bukan pembangunan Indonesia. Disempowerment ini berkelanjutan dengan makin dibiarkannya pengangguran dan kemiskinan rakyat makin meluas. Kebijaksanaan ekonomi yang mengutamakan pertumbuhan dan mengabaikan perluasan lapangan kerja bukanlah hanya suatu kelengahan (mindset dari kelompok market fundamentalists), tetapi patut diwaspadai sebagai suatu kepentingan untuk mendominasi dan melanggengkan ketergantungan nasional. Maka perlu upaya islamisasi ilmu ekonomi yang mengarah pada keselarasan antara dimensi etis ekonomi dan dimensi praktisnya (bisnis) dalam pengertian yang integratif, tidak parsial dengan tujuan membangun masyarakat yang berkeadilan. Hal ini tentunya berbeda dengan aksioma kapitalis bahwa kegiatan ekonomi (bisnis) itu mempunyai tujuan ekonomis yaitu keuntungan meteriil sehingga keuntungan menjadi ideologinya dalam berbisnis meskipun harus mengorbankan nilai-nilai moral ethics.
\end{abstract}

Keyword: Islamisasi, Ilmu Ekonomi, Masyarakat Berkeadilan.

\section{PENDAHULUAN}

\section{A. Latar Belakang Masalah}

Forum resmi pertama kali yang memunculkan gagasan perlunya mencari epistemologi Islam ini adalah Konferensi Dunia tentang Pendidikan Muslim yang pertama di Makkah pada tahun 1977. Dalam forum tersebut, Syed Naquib al Attas melontarkan argumennya dengan gamblang tentang perlunya pembentukan epistemologi Islam. Selain itu, Ismail al Faruqi juga memiliki pendapat serupa, tetapi ketika itu, ia hanya menekankan perlunya "mengislamisasikan" ilmu-ilmu sosial ${ }^{1}$. Islamisasi Pengetahuan ini telah menjadi tema dan term populer di kalangan intelektual muslim maupun di negara-negara lain. Istilah ini telah menjadi simbol dari sebuah keinginan besar untuk memberi warna Islam pada berbagai disiplin ilmu. Meski demikian, gagasan ini tetap melahirkan tanggapan beragam dari kalangan intelektual muslim, banyak yang mendukung dengan berbagai alasan dan tidak sedikit juga yang menyikapi secara kritis atau bahkan menolak dengan

1 Dr. Mahdi Ghulsyani, Filsafat Sains menurut al Qur'an (terj), (Bandung: Mizan, 1994) Cet VII hlm 22. 
berbagai argument.

Menurut Dawam Rahardjo (1995: 32) upaya islamisasi ilmu ekonomi harus dimulai dari penguatan etika bisnis sebagai upaya mewujudkan masyarakat berkeadilan yang beroperasi pada tiga tingkat, yaitu; individual, organisasi, dan sistem. Pada tingkat individual, etika bisnis mempengaruhi pengambilan keputusan seseorang, atas tanggungjawab pribadinya dan kesadaran sendiri, baik sebagai penguasa maupun manajer. Pada tingkat organisasi, seseorang sudah terikat kepada kebijakan perusahaan dan persepsi perusahaan tentang tanggungjawab sosialnya. Pada tingkat sistem, seseorang menjalankan kewajiban atau tindakan berdasarkan sistem etika tertentu. Realitasnya, para pelaku bisnis sering tidak mengindahkan etika. Nilai moral yang selaras dengan etika bisnis, misalnya toleransi, kesetiaan, kepercayaan, persamaan, emosi atau religiusitas hanya dipegang oleh pelaku bisnis yang kurang berhasil dalam berbisnis. Sementara para pelaku bisnis yang sukses memegang prinsip-prinsip bisnis yang tidak bermoral, misalnya maksimalisasi laba, agresivitas, individualitas, semangat persaingan, dan manajemen konflik (Dawam Rahardjo, Ibid: 16). Hal ini tidak hanya di Dunia Timur, di Dunia Barat atau negaranegara industri maju, citra bisnis tidak selalu baik. Setidak-tidaknya seperti yang dikatakan oleh Withers (Ibid.) bahwa dalam bisnis itu pada dasarnya berasaskan ketamakan, keserakahan, dan semata-mata berpedoman kepada pencarian laba.

Benar apa yang diungkapkan oleh Sayyid Quthb (Quraish Shihab, 1997: 4), bahwa bisnis atau kegiatan ekonomi merupakan aktivitas pertama yang menanggalkan etika, disusul kemudian oleh politik, dan terakhir seks.

Dalam tulisan ini akan mengkaji praktek madzhab ekonomi dunia, yakni kapitalisme di Amerika Serikat apakah bermoral atau tidak? Bagaimana kritik Marx terhadap praktek kapitalisme tersebut, bagitu kritik non-Marxis? Lantas bagaimana Islam melihat praktek kapitalisme tersebut? Dan bagaimana etika bisnis dalam Islam?

Islam dijadikan alat kritik terhadap praktek kapitalisme dengan asumsi bahwa perkembangan ilmu ekonomi sejak abad XVII sampai sekarang mengalami perubahan paradigma, dari paradigma merkantilis, fisiokrat, klasik, neo-klasik, marxian, keynesian, dan yang terakhir paradigma Syari'ah (Muhammad Arif, 1985: 92-94).

\section{B. Rumusan Masalah}

Permasalahan-permasalahan yang akan dikaji dalam penelitian ini, dirumuskan sebagai berikut:

1. Sejauh manakah upaya islamisasi ilmu ekonomi itu?.

2. Bagaimanakah konsep ilmu ekonomi Islam yang mampu mewujudkan masyarakat berkeadilan?.

\section{PEMBAHASAN}

\section{A. Definisi Ilmu Ekonomi Sekuler dan Ilmu Ekonomi Islam}

Sebagai langkah awal pembahasan, penulis terlebih dahulu akan memperjelas bahwa keberadaan ilmu ekonomi Islam merupakan sebuah ilmu tersendiri. Hal ini bisa kita pahami dengan baik, jika kita bisa membandingkan antara ilmu ekonomi Islam dengan ilmu ekonomi sekuler hingga tampak perbedaan di antara keduanya. 
Sedangkan ilmu ekonomi Islam didefinisikan Hasanuzzaman sebagaimana dikutip Imamuddin Yuliadi adalah: Ilmu dan aplikasi petunjuk serta aturan syari'ah yang mencegah ketidakadilan dalam memperoleh dan menggunakan sumberdaya material agar dapat menjalankan kewajibannya kepada Allah dan masyarakat. Atau dalam definisi Abdul Mannan adalah ilmu sosial yang mempelajari masalahmasalah ekonomi masyarakat dalam perspektif nilai-nilai Islam² ${ }^{2}$

Dari definisi di atas jelaslah bahwa ekonomi sekuler sama sekali tidak mengaitkan studi yang dilakukan dalam kerangka ilmu ekonomi dengan keberadaan Allah, termasuk syariat Nya. Jadi jelaslah perbedaan yang mendasar antara keduanya. Dalam ekonomi Islam ada elemen-elemen yang tak dapat ditawar lagi sebagaimana tercantum dalam al-Qur'an dan sunah Nabi seperti larangan riba, menipu, berbuat curang dan lain sebagainya. Atau dengan kata lain, hal yang membedakan antara ekonomi sekuler dan ekonomi Islam adalah adanya nilai-nilai moral yang ada di dalamnya.

Menurut ilmu ekonomi Islam, bahwa antara dimensi etis ekonomi dan dimensi praktisnya (bisnis) harus dipahami dalam pengertian yang integratif, tidak parsial. Hal ini tentunya berbeda dengan aksioma kapitalis bahwa kegiatan ekonomi (bisnis) itu mempunyai tujuan ekonomis yaitu keuntungan meteriil sehingga keuntungan menjadi ideologinya dalam berbisnis meskipun harus mengorbankan nilai-nilai moral ethics karena sebagaimana pendapat Richard T. De George bahwa antara bisnis dan moralitas itu tidak ada kaitannya sama sekali ${ }^{3}$. Masing-masing berdiri di wilayahnya sendiri. Dalam sistem ekonomi Islam nilai-nilai etika yang dimaksud seperti kesatuan (unity), equilibrium (keseimbangan atau keadilan)4, kebebasan yang terbatas pada hak-hak orang lain, pertanggungjawaban ${ }^{5}$, kebajikan dan kejujuran ${ }^{6}$.

\section{B. Hubungan Antara Agama Islam Dan Ekonomi}

Layaknya penjelasan hubungan antara agama dan ilmu, ekonomi yang diyakini sebagai salah satu cabang ilmu secara otomatis tidak dapat dipisahkan dengan agama. Terlebih lagi Al Qur'an \& As Sunnah sebagai sumber hukum dari semua perkara, memberikan porsi yang cukup besar dalam membahas berbagai hal berkaitan dengan ekonomi. Bahkan prinsip, metodologi dan hukum pengaturan perekonomian dalam Islam tidak bisa dipisahkan dengan Islam sebagai agama. Misalnya saja mekanisme zakat, zakat dalam Islam merupakan salah satu rukun atau pilar utama agama, dimana urgensi zakat dapat dipersamakan dengan empat pilar utama lainnya yaitu dua kalimat syahadat, shalat lima waktu, puasa ramadhan dan haji. Mengabaikan zakat sama saja dengan mengamputasi Islam sebagai agama, karena zakat menjadi salah satu rukunnya.

Demikian sebaliknya, dalam ekonomi zakat menjadi pilar penting agar mekanisme atau proses ekonomi dapat terus berlangsung. Zakat pada dasarnya menjaga agar daya beli masyarakat khususnya golongan bawah (mustahik) selalu

2 Imamuddin Yuliadi, Ekonomi Islam, Sebuah Pengantar (Yogyakarta: LPPI, 2001) hlm. 7

3 Richard T. De George, Bussines Ethics (New Jersey: Prentile Inc. A. Simon and Schuster Company, 1990) hlm. 3-4 sebagaimana dikutip oleh Abdul Mugits, Epistemologi Ilmu Ekonomi Islam dalam Hermeneia Jurnal Kajian Islam Interdisipliner Vol. 2 No. 2 Juli-Desember 2003 hlm. 179

4 Prinsip tersebut sebagaimana ditegaskan dalam al-Qur'an QS 2:195; 25:67-68, 72-73; 17:35; dan 59:7

5 QS 4:85

6 QS 5:1; 6:152; 16:91; 17:34-35; 7:85; 11:85 dan 26: 181-183 
ada. Atau zakat memberikan kesempatan pada masyarakat yang tidak memiliki akses pada ekonomi, sehingga semua elemen masyarakat dapat terlibat aktif dalam aktifitas ekonomi. Dengan kata lain, zakat adalah satu instrumen ekonomi yang menjaga agar tingkat minimum permintaan yang dibutuhkan oleh pasar agar pasar dapat berjalan dapat selalu terpelihara. Zakat juga secara tidak langsung mampu menekan atau bahkan menghindarkan masyarakat dari masalah-masalah sosial lainnya, seperti pengangguran, kemiskinan, kriminalitas dan konflik sosial.

Berdasarkan alasan ini, sukar untuk mendikotomikan agama dan ekonomi dalam Islam, karena memang ekonomi menjadi salah satu sistem berkehidupan yang diatur oleh agama, agar harmonisasi, keseimbangan dan kesejahteraan dapat dicapai dan terjaga keberlangsungannya. Terlebih lagi diyakini bahwa Islam merupakan nilai atau sistem komprehensif yang mampu mengatur secara baik semua aktifitas hidup dan kehidupan manusia.

Sejalan dengan penjelasan sebelumnya, dalam dunia konvensional nafas sekularisme pun berhembus dalam pembahasan ekonomi. Pemisahan agama dari disiplin ilmu ekonomi sudah tentu menjadi prasyarat sekularisme. Pemikiran dari para pakar ilmu sosial setelah periode reneisance menggambarkan kondisi dikotomi ini. Pemisahan bukan hanya terjadi antara ekonomi dangan agama, bahkan terjadi pada ekonomi dengan segala bentuk nilai moral, entah itu yang berasal dari nilainilai ilahiyyah ataupun dari pemikiran manusia.

Karena ekonomi merupakan bagian dari kelompok disiplin ilmu sosial yang banyak bicara tentang prilaku manusia, maka dalam membahas ekonomi dari sisi konvensional akan relative kurang lengkap jika tidak membahas akar teori prilaku ekonomi dalam dunia sosiologi. Berdasarkan pendapat Prof. Dr. Alex Lanur, Jeremy Bentham (1748-1823) sebagai Bapak Utilitarianisme, cukup tegas dalam menjelaskan motivasi dan batasan berprilaku manusia (tentu saja dalam pandangan konvensional). Menurut Lanur, dasar Benthanisme adalah hedonisme psikologis yaitu bahwa setiap manusia menurut kodratnya berusaha untuk mengejar kesenangan (pleasure) dan menghindari rasa sakit (pain). Pernyataan Bentham yang sangat terkenal berkaitan dengan hal ini adalah "alam menempatkan manusia di bawah dua kekuasaan yang berdaulat, yakni rasa sakit dan kesenangan". Dengan demikian, asumsi yang digunakan oleh Bentham adalah; pertama, kesenangan yang paling besar adalah yang jumlahnya paling banyak (the greatest happiness of the greatest number). Kedua, tindakan yang baik adalah segala tindakan yang mengarahkan manusia menambah jumlah kesenangan, sementara tindakan yang tidak mengarah kepada kesenangan atau yang mengurangi jumlahnya adalah tindakan yang tidak baik. Pada akhirnya asumsi ini membentuk prinsip yang oleh Bentham disebut sebagai prinsip manfaat atau Prinsip Etis Terakhir (ultima principia). Selanjutnya Bentham menjelaskan faktor-faktor yang dapat menjadi ukuran dari kesenangan ini (cara menentukan, menilai atau menghitung), yaitu meliputi intensitasnya, lamanya, pasti-tidak pastinya dan jauh dekatnya kesenangan atau rasa sakit untuk seseorang. Ternyata Bentham juga tidak membatasi prinsip manfaat pada wilayah individual tapi juga kepentingan umum, dimana faktor yang dapat menjadi ukurannya adalah faktor luasnya atau besar jumlah atau banyaknya orang yang mengalami kesenangan ataupun rasa sakit itu. Penerus pemikir Benthamisme yang paling dikenal adalah John Stuart Mill, dimana Mill mencoba untuk menjelaskan perbedaan kualitatif intrinsik pelbagai macam kesenangan.

Tidak lengkap rasanya jika membahas filosofi dasar kapitalisme tanpa 
menyinggung apa yang menjadi pemahaman Adam Smith (1776) tentang prinsipprinsip dasar ekonomi kapitalis. Adam Smith sebagai Bapak ekonomi, dalam buku Spencer J. Pack, disebutkan berkeyakinan bahwa kapitalisme berkembang berdasarkan kepentingan pribadi pelaku ekonomi. Smith mengidentifikasi bahwa sentimen, perasaan dan nafsu adalah motivator utama manusia dalam bertindak. Bahkan Smith berkeyakinan bahwa teologi (agama,) dalam hal ini Smith merujuk pada Bible, bukanlah merupakan sumber yang terjamin kebenarannya. Oleh sebab itu menurut Smith, kapitalisme muncul dan berkembang secara dominan akibat proses respon kolektif masyarakat terhadap prilaku-prilaku individual (the constant feedback of society to the actions of the individual) bukan karena hasil dari proses sistematis yang terencana (conscious planning). Disini secara implicit Smith mengesampingkan peran dan fungsi agama (terlebih Islam) yang nyatanyata memiliki konsep dan hukum sistematis dalam perekonomian. ${ }^{7}$

Pemikiran Bentham, Mill dan Smith ini kemudian diketahui sebagai nilai dasar dari ekonomi oleh para ekonom-ekonom klasik seperti Alfred Marshall dan F.Y Edgeworth. Elaborasi hal ini akan dibahas pada bab-bab selanjutnya, khususnya pada pembahasan prilaku ekonomi (economic behavior). Berdasarkan nilai dasar keilmuan sosial Barat tentang prilaku manusia, maka dapat dengan jelas dilihat bahwa Islam sebagai sebuah sistem nilai dan hukum yang menjadi inspirasi dan panduan dari semua cabang ilmu cukup berbeda dengan apa yang dikembangkan oleh Barat. Sudah cukup tegas yang berkembang dalam keilmuan Barat adalah keilmuan yang sangat bersifat materi dengan instrumen pengukurnya metode-metode empirik kuantitatif. Sementara Islam dengan nilai-nilai tauhid dan akhlak atau moral seta hukum syariah muamalah yang sangat menentukan prilaku dan praktek ekonomi, membuat ekonomi sukar untuk dipisahkan dengan agama. Karena bisa dikatakan ekonomi merupakan salah satu bagian dari agama Islam itu sendiri. Sehingga pada akhirnya yang membedakan keduanya adalah keyakinan pada unity atau dichotomy antara agama dan ilmu termasuk didalamnya ekonomi.

\section{Latar Belakang Islamisasi Ilmu Ekonomi}

Munculnya gagasan islamisasi ilmu ekonomi adalah bersamaan dengan ide islamisasi ilmu pengetahuan yang mana semuanya berangkat dari adanya suatu kesadaran teologis dan etis untuk mengembangkan ilmu pengetahuan atas dasar pandangan dunia Islam, setelah disadari paradigma sains modern banyak mendatangkan dampak negatif terhadap perkembangan peradaban manusia modern. Munculnya dampak ini sebagai konsekuensi dari dasar filsafat keilmuan yang meliputi aspek metafisika, epistemologi dan aksiologi yang secara eksplisit tidak mempunyai keterkaitan dengan kepentingan moralitas manusia. Selanjutnya, keringnya nilai-nilai etik dan moral menjadikan sains modern dalam tataran aksiologinya sering menafikan kemaslahatan manusia. Apa yang sekarang disebut sebagi krisis global menunjukkan adanya keterpecahan antara nilai-nilai etik dan sains modern yang berkembang dalam kerangka netralitas etik (free value) ${ }^{8}$.

Tokoh-tokoh Islamisasi Pengetahuan memberi pengertian sendiri-sendiri tentang istilah ini sesuai dengan latar belakang dan keahlian masing-masing.

7 Muhammad dan R.Lukman Faurani. 2002. Visi Al-Qur'an Tentang Etika dan Bisnis. Jakarta: Salemba Diniyah. Hal 92

8 Syamsul Arifin, et al, Spiritualisasi Islam dan Peradaban Masa Depan, (Yogyakarta: Sipress, 1996) hlm. 77 
Menurut Syed Husein Nasr, Islamisasi Pengetahuan adalah upaya menterjemahkan pengetahuan modern ke dalam bahasa yang bias dipahami masyarakat muslim di mana mereka tinggal. Artinya Islamisasi Pengetahuan lebih merupakan usaha untuk mempertemukan cara berpikir dan bertindak (epistemologis dan aksiologis) masyarakat Barat dan Muslim?.

Sementara Naquib al Attas mendefinisikannya sebagai sebuah upaya membebaskan ilmu pengetahuan baru yang sesuai dengan fitrah Islam. Dalam pandangan Naquib, berbeda dengan Nasr, Islamisasi Pengetahuan berkenaan dengan perubahan ontologis dan epistemologis terkait dengan perubahan cara pendang dunia yang merupakan dasar lahirnya ilmu dan metodologi yang digunakan agar sesuai dengan konsep Islam ${ }^{10}$. Menurutnya, proses Islamisasi Ilmu melibatkan dua langkah utama. Pertama ialah proses mengasingkan unsur-unsur dan konsep-konsep utama Barat dari ilmu tersebut dan kedua menyerapkan unsurunsur dan konsep-konsep Islam ke dalamnya. Jelasnya, ilmu hendaklah diserapkan dengan unsur-unsur dan konsep utama Islam setelah unsur-unsur dan konsep pokok asing dikeluarkan dari setiap ranting ${ }^{11}$. Tujuan Islamisasi Ilmu adalah untuk melindungi orang Islam dari ilmu yang sudah tercemar yang menyesatkan dan menimbulkan kekeliruan. Islamisasi ilmu bertujuan untuk mengembangkan ilmu yang hakiki yang boleh membangunkan pemikiran dan pribadi muslim yang akan menambahkan lagi keimanannya kepada Allah. Islamisasi ilmu akan melahirkan keamanan, kebaikan, keadilan dan kekuatan keimanan.

Sedangkan menurut Al Faruqi, Islamisasi Pengetahuan adalah mengislamkan disiplin-disiplin ilmu atau tepatnya menghasilkan buku-buku pegangan (buku daras) di perguruan tinggi dengan menuangkan kembali disiplin-disiplin ilmu modern dalam wawasan Islam setelah dilakukan kajian kritis terhadap kedua system pengetahuan Islam dan Barat ${ }^{12}$. Pengertian ini lebih jelas dan operasional dibanding pengertian sebelumnya disamping dia memberikan langkah-langkah operasional bagi terlaksananya program Islamisasi Pengetahuan ini. Menurut beliau, Islamisasi ilmu dapat dicapai melalui pemaduan ilmu-ilmu baru ke dalam khazanah warisan Islam dengan membuang, menata, menganalisa, menafsir ulang dan menyesuaikannya menurut nilai dan pandangan Islam.

Berdasar beberapa pengertian di atas, Islamisasi Pengetahuan berarti upaya membangun paradigma keilmuan yang berlandaskan nilai-nilai Islam, baik pada aspek ontologism, epistemologis dan aksiologis.

\section{Upaya Islamisasi Ilmu Ekonomi}

Gagasan Islamisasi ilmu ekonomi ini tidak serta merta mendapat respon positif dari kalangan muslim sendiri. Ini tampak dalam kritik yang dilontarkan

\footnotetext{
9 M. Safiq, Islamization of Knowledge, Philosophy and Methodology and Analysis of The Views and Ideas of Ismail Raji al Faruqi, Husein Nasr and Fazlur Rahman dalam Hamdard Islamicus (Vol XVIII, No. 3, 1995) hlm. 70 sebagaimana dikutip oleh A. Khudori Soleh, Wacana Baru Filsafat Islam, (Yogyakarta: Pustaka Pelajar, 2004) hlm. 239

10 Naquib al Attas, Islam and Secularism, (Kuala Lumpur: ABIM, 1978) hlm. 156 dikutip dalam A. Khudori Soleh, Wacana Baru..hlm. 240

11 Naquib al Attas, The Concept of Education in Islam, (Kuala Lumpur: ISTAC, 1991) hlm. 43 dalam Majalah Islamia, Tahun II No. 6/Juli-September 2005

12 Ismail Raji al Faruqi, Islamisasi Pengetahuan (terj), (Bandung: Pustaka, 1995) hlm. 35
} 
Fazlur Rahman dan Ziauddin Sardar. Mereka menolak ide Islamisasi ilmu ekonomi ini karena dinilai menyesatkan dan akan menjadikan prinsip Islam tetap dalam posisi subordinate dari ilmu-ilmu modern. Sardar juga menganggap bahwa proses Islamisasi ilmu ekonomi ini naif dan dangkal, malah justru yang terjadi adalah pembaratan (westernisasi) Islam ${ }^{13}$.

Pembicaraan tentang Islamisasi Ilmu Ekonomi juga menimbulkan dua pihak yang beroposisi. Satu pihak masih sangsi terhadap keberadaan ilmu ini sebagai ilmu yang berdiri sendiri. Mereka meyakini bahwa ilmu ekonomi itu di mana-mana sama. Hal yang bias membedakan adalah moral ekonominya, misalnya menurut ajaran Islam. Nilai-nilai itulah yang seharusnya menjiwai tingkah laku ekonomi dalam suatu sistem perekonomian yang lazim kita kenal yaitu yang sifatnya universal. Hal ini sebagaimana diyakini seorang ahli ekonomi dan teknokrat yang menonjol peranannya di Indonesia pada akhir tahun 40-an dan 50-an yaitu Syafruddin Prawiranegara $^{14}$. Di pihak lain, ada pula yang berpendapat bahwa ekonomi Islam sebagi sebuah konsep, teori atau ilmu setidak-tidaknya bisa disusun yang berbeda dengan misalnya sistem-sistem ekonomi sosialis ataupun kapitalis.

Pembicaraan tentang Islamisasi Ilmu Ekonomi sebenarnya harus dimulai dari sebuah pertanyaan mendasar : apakah ilmu pengetahuan (termasuk ilmu ekonomi) bebas nilai ataukah tidak? Pertanyaan ini menjadi penting karena jawaban "ya" dan "tidak" sama-sama mengandung konsekuensi. Jika kita percaya pada teori yang menyatakan bahwa ilmu pengetahuan itu bebas nilai maka islamisasi ilmu ekonomi itu hanya terjadi pada dataran aksiologis, karena menurut teori ini bahwa sekapitalis apapun teori ekonomi itu jika dipraktekkan oleh pribadi-pribadi Muslim maka dengan sendirinya akan menjadi ekonomi Islam. Hal ini sebagaimana dikatakan Fazlur Rahman bahwa ilmu tidak bisa diislamkan karena tidak ada yang salah di dalam ilmu pengetahuan, masalahnya hanya dalam menyalahgunakannya ${ }^{15}$. Baginya, ilmu pengetahuan memiliki dua kualitas seperti senjata bermata dua yang harus digunakan dengan hati-hati dan bertanggung jawab sekaligus sangat penting menggunakannya secara benar ketika memperolehnya. Pandangan ini tampaknya terlalu simplitis dan menganggap ilmu pengetahuan sebagai sebuah barang mati yang tidak mengandung nilai apa-apa. Padahal, lahirnya sebuah konsep ilmu pengetahuan sama sekali tidak dapat dilepaskan dari konstruksi nilai yang berlangsung di tengah masyarakat. Sedangkan pandangan yang menyatakan bahwa ilmu pengetahuan itu tidak bebas nilai artinya lahirnya sebuah episteme keilmuan sebenarnya tidak bisa dipisahkan dari lingkup zaman yang melingkarinya maka hal itu berimplikasi Islamisasi Ilmu Ekonomi harus dilakukan dalam wilayah ontologi dan epistemologi.

Sebagaimana telah disebutkan dalam definisi bahwa islamisasi ilmu pengetahuan berarti upaya membangun paradigma keilmuan yang berlandaskan nilia-nilai Islam, baik pada aspek ontologi, epistemologi dan aksiologi maka yang penting dilakukan dalam melahirkan sebuah ekonomi Islam ini adalah menggali petunjuk al-Qur'an berdasarkan kerangka ketiganya. Dengan cara itu, kita akan

13 M. Zainuddin, Filsafat Ilmu Perspektif Pemikiran Islam, (Malang: Bayumedia, 2003) hlm. 160-161

14 A. Syafi'i Ma'arif dan Said Tuhuleley, Al-Qur'an dan Tantangan Modernitas, (Yogyakarta: Sipress, 1996) Cet. IV hlm. 47

15 Fazlur Rahman, Islamization of Knowledge: A Respon dalam The American Journal of Islamic Social Science Vol V no. 1 Th 1988 hlm. 3 sebagaimana dikutip oleh Sufyanto (Ed), Cita-Cita Islam, (Yogyakarta: Pustaka Pelajar, 2000) hlm. 111-112 
dapat menemukan dan menyusun suatu kerangka baru dalam ilmu ekonomi. Melalui proses ini, kita bisa menyeleksi warisan ilmu pengetahuan yang ada dan mengembangkan suatu sintesis baru. Dewasa ini kita belum bisa memperoleh atau menyajikan gambaran konkret tentang bagaimana konsepsi sistem ekonomi Islam itu. Yang ada barulah model-model teoritis yang mesti diuji dengan penilitian dan praktek. Body of knowledge dalam kerangka sistem ekonomi Islam baru akan dapat dirumuskan kemudian secara dinamis dan historis.

Al-Qur'an secara jelas telah memberikan petunjuk ontologis yaitu tentang "yang ada" yang mesti diketahui oleh ulul albab. Secara nyata pula, Al-Qur'an memberikan pedoman aksiologis yaitu teori tentang nilai. Pedoman aksiologis ini sangat banyak di dalamnya berupa kerangka dan sistem etika. Yang masih merupakan dunia yang gelap adalah epistemologi Islam yaitu metode penyelidikan ilmiah untuk melaksanakan petunjuk-petunjuk ontologis dalam Al-Qur'an. Pengembangan ilmu ekonomi yang bersumber Islam perlu dimulai dengan studi mendasar yang sifatnya filosofis dan etis itu yaitu dengan pendekatan kritis-radikal terhadap nilai-nilai dan struktur yang mapan. Masalahnya adalah terbentur pada metodologi yang masih sangat lemah dalam penelitian ekonomi Islam itu, kecuali kalau jika kita mengambil begitu saja metodologi dari Barat.

Untuk menghindari kesulitan metodologi, Dawam Raharjo menawarkan beberapa alternatif yaitu pendekatan fenomenologi, riset aksi dan grounded research ${ }^{16}$. Dengan pendekatan fenomenologi, kita bisa melakukan pemahaman gejala secara langsung tanpa diberati oleh nilai-nilai asumtif yang telah menciptakan bias-bias dalam sikap kita. Dengan riset aksi kita langsung melakukan aksi lapangan dan berpedoman kepada kerangka etis. Dari pengalaman aksi itu bisa dibangun teoriteori baru yang lebih realistis dan membumi. Sedangkan dengan grounded research kita tidak terbelenggu oleh teori-teori yang telah mapan. Melalui ketiga alternatif pendekatan itu diharapkan dapat dibina suatu body of knowledge yang merupakan subtansi dari apa yang nanti mungkin dapat disebut sebagai ilmu ekonomi Islam yang operasional.

\section{E. Konsep Ilmu Ekonomi Islam Dalam Upayanya Mewujudkan Masyarakat Berkeadilan}

Jika sumber-sumber daya merupakan suatu bentuk amanah dari Allah dan manusia akan mempertanggungjawabkannya di hadapan-Nya , maka tak ada opsi, kecuali menggunakannya dengan keadilan. Al-Qur'an dan as-Sunnah menempatkan penekanan tegas terhadap keadilan, menjadikannya salah satu tujuan pokok syariat. Persaudaraan, salah satu tujuan syariat pokok lainnya akan hampa sekiranya tidak diperkuat oleh keadilan dalam alokasi dan distribusi sumber-sumber daya yang telah diberikannya. Menurut Al-Qur'an, penegakan keadilan merupakan salah satu tujuan pokok Allah menurunjan para rasul (al-Hadiid:25). Al-Qur'an menempatkan posisi keadilan paling dekat kepada ketakwaan. Ketakwaan, dengan demikian, merupakan hal yang paling penting karena berfungsi sebagai batu loncatan bagi semua amal saleh, termasuk keadilan. Rasulullah saw. Menyamakan ketiadaan keadilan dengan "kegelapan mutlak" dan memperingatkan "takutlah kepada kezaliman karena kezaliman akan menyebabkan kegelapan pada hari

16 M Dawam Raharjo, Perspektif Deklarasi Makkah Menuju Ekonomi Islam, (Bandung: Mizan, 1993) Cet IV hlm. 108 
kiamat". Ini merupakan keniscayaan karena merupakan kezaliman menghapuskan persaudaraan dan solidaritas, mempertajam konflik, ketegangan dan kejahatan, memperburuk problem kemanusiaan, dan pada gilirannya akan mengantarkan kepada kegelapan di dunia dan azab di akhirat (Chapra,2001:56).

Islam memerintahkan keadilan dalam seluruh persoalan yang berhubungan dengan masyarakat manusia. Ajaran-ajaran Islam yang mendasar terkandung di dalam Al-Qur'an dan Sunnah. Pada masa Rasulullah dan Kulafaur Rasyidin, memberikan gambaran hidup mengenai pelaksanaan ajaran-ajarannya secara praktis. Pandangan Islam terhadap sebuah tatanan sosio-ekonomi dapat disimpulkan berkenan dengan ajaran-ajaran dasar tersebut dan catatan sejarah dari periode Islam yang pertama.

Menurut Al-Qur'an, tujuan utama Tuhan memberikan petunjuk melalui utusan-Nya adalah agar umat manusia mampu mendirikan keadilan, seperti firman Allah :

"Sesungguhnya Kami telah mengutus Rasul-rasul Kami dengan membawa bukti-bukti yang nyata dan telah Kami turunkan bersama mereka Al Kitab dan neraca (keadilan) supaya manusia dapat melaksanakan keadilan" (QS. 57:25).

Tuhan telah menciptakan manusia sebagai wakil-Nya di muka bumi, seperti dalam firmanNya :

"Sesungguhnya Aku hendak menjadikan seorang khalifah di muka bumi" (QS. 2:30)

Allah memerintahkan manusia untuk berlaku adil pada setiap orang, seperti dalam firman-Nya :

"Berlaku adillah, karena adil itu lebih dekat kepada taqwa. Dan bertaqwalah kepada Allah. Sesungguhnya Allah Maha Mengetahui apa yang kamu kerjakan." (QS.5:8).

Tidak ada permasalahan yang lebih dekat hubungannya dengan konsep keadilan daripada 'hak-hak asasi manusia'. Sumber hukum Islam yang pertama (syariah), yaitu Al-Qur'an, meletakkan elemen-elemen yang fundamental dari sebuah piagam hak-hak asasi manusia yang mana memiliki kekuatan mengikat, baik tanggungjawab moral maupun sistem hukum. Dan lebih lanjut, dilengkapi dengan sumber hukum Islam yang kedua, yaitu perkataan dan perbuatan Nabi SAW, yang biasa dikenal dengan sebutan Sunnah. Dengan menggabungkan keduanya, mereka menjanjikan penghilangan segala bentuk eksploitasi, penindasan, dan ketidakadilan (Iqbal, 1994).

Seluruh hak-hak asasi manusia yang diberikan oleh Islam didasarkan pada prinsip 'kemaslahatan umum' (al-maslahah-al-'ammah). Hak-hak asasi manusia yang diberikan oleh Islam didasarkan pada prinsip 'Kemaslahatan umum' (al-maslahah al-'ammah). Hak-hak asasi tersebut yang memiliki hubungan khusus dengan permasalahan kajian ini adalah sebagai berikut :

a. Hak untuk hidup. Kehidupan manusia adalah suci dan tidak dapat diganggu gugat, serta setiap usaha (karya) diciptakan untuk melindungi kehidupan manusia itu sendiri.

b. Kebebasan profesi (pekerjaan). Ada kebebasan untuk memasuki semua profesi yang diperkenankan oleh Islam.

c. Semua orang adalah sama di hadapan hukum dan berhak terlindungi oleh hukum sesuai dengan syariah.

d.Setiap orang berhak untuk memiliki harta kekayaan baik secara pribadi ataupun bekerjasama dengan pihak lain. Negara memiliki kekuasaan yang sah terhadap sumber-sumber daya ekonomi tertentu bagi kepentingan umum. 
e. Kaum miskin berhak atas kekayaan kaum kaya sedemikian sehingga kebutuhan dasar setiap orang dalam masyarakat dapat dipenuhi.

f. Eksploitasi manusia pada tingkat tertentu, atau bentuk tertentu, ataupun dalam keadaan bagaimanapun juga adalah anti Islam dan harus diakhiri.

Kesejahteraan yang berkeadilan adalah komponen yang terpenting dalam tatanan ekonomi kesejahteraan dan keadilan syariah.. Segi yang paling patut diperhatikan dalam skema kesejahteraan yang berkeadilan sebagaimana dipertimbangkan oleh Islam adalah adanya jaminan pemenuhan kebutuhan dasar bagi seluruh rakyat, terlepas dari tahapan pembangunan sebuah negara. Hal ini menyiratkan secara tidak langsung pemberantasan yang sempurna terhadap apa yang disebut dalam literatur perekonomian mutakhir sebagai ' kemiskinan absolut'. Aspek yang kedua dari kesejahteraan yang berkeadilan yang adalah berkaitan dengan pola umum pemerataan pendapatan di dalam masyarakat. Dalam hal ini, tinjauan Islam lebih fleksibel di mana garis pedoman untuk pola pemerataan pendapatan dan kekayaan yang diharapkan terkandung dalam AL Qur'an dan Sunnah, yang tertulis dalam ketentuan-ketentuan umum dan memperkenankan banyak sekali kebijaksanaan dalam menghadapi persoalan ini.

Desakan Islam terhadap pemenuhan kebutuhan dasar bagi seluruh umat manusia harus dilihat dalam segi pandangan Islam mengenai tempat manusia di alam semesta. AlQur'an mengumumkan bahwa Tuhan telah memberi kehormatan pada anak cucu Adam dan telah membuat ketetapan hal-hal yang baik untuk mereka. Manusia merupakan wakil-Nya di muka bumi, dan adalah tugas manusia untuk menata urusan-urusan dunia dimana semua orang memiliki kewajiban untuk berbagi 'hal-hal yang baik' dari kehidupan. Tuhan telah menyediakan seluruh sumber-sumber daya yang diperlukan bagi pemenuhan kebutuhan dasar umat manusia, apapun yang diciptakan di surga dan bumi, telah diciptakan untuk tunduk pada manusia. Sumber-sumber daya tersebut diciptakan oleh-Nya sebagai hadiah untuk seluruh umat manusia dan apa saja yang menjadi milik seorang individu akan diperlukan sebagai 'titipan'. Titipan ini tidak dapat dikatakan untuk dilepas kecuali jika masing-masing atau setiap orang cukup mendapatkan kepuasan sedikitnya kebutuhan dasarnya.

Kepercayaan agama Islam memberi tekanan pada sifat tidak kekalnya kehidupan manusia di bumi dan mendorong manusia untuk melakukan perbuatan yang baik demi keselamatannya di Akhirat. Namun demikian, amatlah ditentang penolakan terhadap dunia ini demi memperoleh kebahagiaan di Akhirat. Dengan jelas Al Qur'an menyatakan bahwa Tuhan menginginkan kemudahan bagi umat manusia dan bukannya kesukaran. Demikian sabda Nabi SAW dengan jelas menyatakan bahwa kemiskinan dan deprivasi (perampasan) bukanlah merupakan suatu kebaikan yang patut dihargai oleh Islam, dan setiap usaha mesti dilakukan untuk menghilangkan kemiskinan dan deprivasi tersebut.

Untuk menjamin terpenuhinya kebutuhan dasar bagi seluruh masyarakat, Islam menetapkan suatu prinsip bahwa kaum miskin memiliki 'hak' (haqq) atas pendapatan dan kekayaan para anggota masyarakat yang mampu. Menurut Islam, umat manusia adalah satu-satunya ciptaan Tuhan, dan seluruh manusia mempunyai hak yang sama untuk memperoleh makanan dari sumber-sumber daya pemberian Tuhan. Betapapun, untuk alasan tertentu, jika ada beberapa anggota persaudaraan manusia yang gagal memperoleh persediaan yang cukup untuk memenuhi kebutuhan dasar mereka dengan melalui usaha mereka sendiri, maka 
mereka berhak atas penghasilan dan kekayaan anggota-anggota lain.

Islam menggunakan baik peringatan moral maupun aturan hukum untuk menghilangkan kemiskinan dan deprivasi, sehingga kebutuhan dasar bagi seluruh rakyat dapat dipenuhi sebagaimana mestinya. Sejumlah ayat dalam Al Qur'an menekankan kebaikan infaq, yaitu pemberian sukarela untuk kesejahteraan kaum miskin. Sebagai contoh, telah dinyatakan bahwa tidak ada perkara dimana manusia akan mencapai kesalehan kecuali jika ia dengan rela mengeluarkan kekayaannya dengan cara yang diatur oleh Tuhan untuk mereka yang melarat dan kaum fakir miskin. Bagi mereka yang melakukan infaq telah dijanjikan menjadi orang-orang pilihan yang memperoleh kenikmatan di surga. Nabi SAW sendiri menjadikan dirinya sebagai contoh teladan dalam banyak memberi untuk kesejahteraan kaum miskin. Beliau mendesak para pengikutnya agar saling mengungguli dalam memberi pertolongan kepada kaum miskin. Beliau juga tiada henti-hentinya mengingatkan para pengikutnya bahwa sebuah masyarakat yang gagal memelihara kebutuhan kaum fakir miskin tidak dapat dipandang Islami. Demikian beliau pun memberi peringatan kepada para pengikutnya apabila ada suatu tempat dimana seorang masih kelaparan di malam hari maka Tuhan akan meninggalkan mereka.

Islam sangat peduli bahwa kaum miskin mesti ditolong dengan cara tertentu yang tidak membuat harga diri mereka terluka. Cara yang terbaik untuk menolong orang miskin, maka seorang pengangguran disumbang dengan bantuan tertentu yang mampu membuat drinya berdiri sendiri. Al Qur'an memerintahkan orang untuk pergi dan mencari orang-ornag tertentu yang membutuhkan tetapi tidak membiarkan mereka mengulurkan tangan untuk meminta. Al Qur'an juga memberi peringatan bahwa derma menjadi kurang bernilai di hadapan Tuhan apabila derma tersebut diikuti dengan suatu tindakan yang melukai perasaan si penerima.

Islam mengakui bahwa masyarakat tidak berperilaku seragam dalam berbuat sesuai dengan ajaran moral untuk menolong kaum fakir miskin melalui sebuah sistem jaminan sosial yang sangat kuat. Islam memerintahkan negara bertugas menghimpun retribusi wajib yang dikenal dengan zakat dari hasil pendapatan bagian masyarakat yang mampu diperuntukkan bagi tujuan-tujuan tertentu dalam rangka menolong kaum fakir miskin yang dapat diperhitungkan secara jelas. Sistem jaminan sosial ini diatur dijaman Nabi SAW. dan berfungsi secara efektif pada periode Islam pertama dan dalam beberapa waktu tertentu pada periode berikutnya. Pada kenyataannya, catatan sejarah memperlihatkan bahwa terdapat beberapa contoh dalam periode ini dimana pada daerah-daerah tertentu tidak ditemukan seorang fakir miskin yang dipandang bisa memperoleh derma.

Para penguasa pada periode islam yang pertama sangat menyadari tanggungjawab mereka terhadap pemenuhan kebutuhan dasar seluruh warga negara. Keempat khalifah pertama yang berkuasa memerintah negara-negara Islam setelah wafatnya Nabi SAW. telah menganggap pemenuhan kebutuhan sebagai salah satu tujuan dasar dari kebijaksanaan negara. Dalam periode khalifah pertama, Abu Bakar, ada segolongan penduduk yang telah menolak untuk membayarkan zakat. Penolakan mereka untuk membayar zakat dipandang sebagai sebuah tindakan pemberontakan yang menentang negara sehingga tindakan yang bersenjata dilakukan untuk melawan mereka sampai mereka sependapat untuk membayar zakat. Khalifah kedua, Umar, juga sangat menyadari tanggungjawab ini sehingga ia mengumumkan: 'Jika seekor unta mati tanpa perawatan di tepi sungai Eufrat, saya takut Allah akan meminta pertanggungjawaban saya terhadap hal itu. 
Para ahli fiqh Islam telah menulis secara mendalam mengenai prinsip pemenuhan kebutuhan. Mereka semua setuju bahwa secara umum pemenuhan kebutuhan merupakan kewajiban masyarakat bersama sehingga tak seorangpun yang dijumpai masih merasa kehilangan keperluan hidup yang mendasar. Sejumlah ahli fiqh Islam mempunyai suatu pandangan bahwa perlindungan hukum harus diberikan sesuai dengan prinsip pemenuhan kebutuhan sehingga setiap warga negara bisa melapor ke pengadilan agar mendapat jaminan pelaksanaan atas prinsip tersebut.

Para ahli fiqh juga telah membahas pertanyaan penting mengenai identifikasi kebutuhan-kebutuhan dasar yang harus dipenuhi bagi seluruh warga negara. $\mathrm{Al}$ Qur'an dan sunnah telah berulang kali menekankan pemberian makanan kepada mereka yang sedang kelaparan, demikian pemenuhan kebutuhan gizi bagi setiap oarng harus diperhitungkan secara jelas untuk meringankan penderitaan kaum miskin. Adapun pemenuhan kebutuhan dasar lainnya yang menempati prioritas tinggi adalah pakaian dan perumahan. Para ahli fiqh Islam telah menjelaskan bahwa selain makanan, pakaian dan perumahan yang diperlukan untuk mempertahankan kelangsungan hidup, maka ada beberapa kebutuhan tertentu lainnya yang harus diperhatikan oleh masyarakat Islam. Literatur para ahli hukum membatasi perbedaan antara tiga jenis kebutuhan manusia dan diklasifikasikan sebagai daruriyyat (kebutuhan), hajiyyat (kesenangan) dan tahsiniyyat (kehalusan budi). Kebutuhan tidak saja termasuk hal-hal yang berkaitan dengan usaha untuk menjaga nafs (fisik luar manusia) melainkan juga hal-hal yang dapat melindungi din (agama), 'Aql (intelek atau pikiran), nas (keturunan) dan mal (harta kekayaan). Hajiyyat meningkatkan kualitas kehidupan dan menghilangkan, baik penderitaan maupun kesukaran sementara tahsiniyyat menambah keindahan dan kecantikan hidup tanpa melampaui batas-batas yang berlebihan. Adalah pandangan para ahli hukum Islam bahwa merupakan tanggung jawab masyarakat bersama untuk menjamin pemenuhan daruriyyat dalam perkara apapun dan juga hajiyyat apabila sumber-sumber dayanya memungkinkan. Telah diakui bahwa karena perubahanperubahan keadaan maka pembatasan terhadap tiga jenia kebutuhan yang disebutkan tadi tidak dapat berlaku secara terus menerus dari waktu ke waktu. Yang terpenting adalah jaminan pemenuhan kebutuhan dasar harus tersedia bagi setiap individu, bahkan ketentuan yang jelas terhadap kebutuhan dasar tersebut dan unsure-unsur pokok dim luar itu yang beragam dapat dipuaskan dalam waktu kapan saja, harus diputuskan sesuai dengan kondisi yang nyata dan standar hidup rata-rata sebuah Negara.

Terlepas dari usaha pembrantasan kemiskinan absulot dan uapaya pemenuhan kebutuhan dasari bagi seluruh umat manusia, maka pandangan islam terhadap sebuah tatanan sosio-ekonomi yang adil juga mempertimbangkan pola pemerataan pendapatan dan kekayaan. Al Qur'an dan Sunnah membuat penjelasan lebih lanjut bahwa Islam tidaklah mencari upaya pelenyapan semua bentuk ketidakadilan dalam pendapatan dan kekayaan. Pada kenyataannya, hal tersebut memperlihatkan kehadiran perbedaan pendapatan tertentu sebagai bagian dari rencana Tuhan atas segala sesuatu. Al Qur'an mengemukakan bahwa Tuhan meninggikan kehidupan dan derajat social beberapa orang di atas orang-orang lain sedemikian sehingga 'beberapa orang tersebut dapat menggunakan jasa orangorang lain dalam pekerjaan mereka. Dalam perkataan lain, Islam menghargai perbedaan pendapatan tertentu sebagaimana mestinya demi kepentingan laju ekonomi yang lancar. 
Islam secara tegas mencela ketidak merataan pendapatan yang ditimbulkan dari praktek - praktek yang eksploitatif. Akan tetapi, bukan berarti Islam menetang perbedaab pendapatan, selama pendapatan itu secara umum merupakan usaha yang jujur dari jenis kegiatan ekonomi yang beragam dan dibolehkan. Al Qur'an memerintahkan : 'Berilah takaran yang penuh, dan janganlah menjadi orangorang yang suka memberi sedikit (dari yang seharusnya), menunjukkan bahwa orang seharusnya mendapatkan kompensasi yang adil atas pekerjaan mereka sepadan dengan kecakapan dan usaha mereka. Walaupun Islam tidak menentang kebedaraan perbedaan pendapatan dan kekayaan tertentu di dalam masyarakat, Islam tetap tidak menyetujui kelaziman ketidakmerataan pendapatan dan kekayaan yang menyolok. Al Qur'an berhati-hati terhadao ketidakmerataan pendapatan dan kekayaan yang menyolok dimana dalam ayat 59:7 menyebutkan bahwa kekayaan diperbolehkan menjadi barang dagangan yang beredar diantara kaum kaya saja di antara kamu' Ajaran Islam, baik yang berkaitan dengan perilaku pribadi atau kebijaksanaan Negara, mempunyai orientasi redistribusi yang tegas. Keadilan social adalah salah satu aspek yang tidak dapat dicabut dari keimanan Islam, dan demikian pula ketidakmerataan pendapatan dan kekayaan yang menyolok kecuali malah mengotori jiwa keimanan.

Patut diperhatikan bahwa bertentangan dengan desakan yang tetap terhadap pemenuhan kebutuhan dasar bagi seluruh umat manusia dalam setiap keadaan dan waktu, maka Isalam tidak menetapkan standar yang kaku terhadap pemerataan pendapatan dimana seluruh masyarakat dalam semua umur harus menyesuaikan diri sebagaimana mestinya. Tidak ada konsep tentang batas-batas jumlah kekayaan individu meski norma-norma mengenai penghasilan dan pengeluaran kekayaan secara jelas telah ditetapkan. Tampaknya adalah tujuan Islam agar tingkat ketidak merataan pendapatan yang dapat diterima ditentukan oleh masyarakat mengingat hal ini berkaitan dengan keadaan mereka sendiri. Islam berupaya untuk meningkatkan sepenuhnya pemikiran saling ketergantungan fungsi pemanfaatan. Islam juga sama sekali mengutuk pemakaian kekayaan yang dibelanjakan secara berlebih-lebihan dan komsumsi yang menyolok. Kedua hal ini mencerminkan adapt istiadat sosial sebuah masyarakat dan memiliki hubungan yang penting dengan tingkat ketidakmerataan yang dapat diterima. Tidak ada cara apapun untuk menetapkan pemerataan pendapatan yang optimal kecuali jika cukup diketahui oleh adat istiadat social dari sebuah masyarakat. Betapapun, memang dapat dinyatakan secara umum bahwa adapt istiadat suatu masyarakat yang didasari oleh semangat al - 'adl dan al - ihsan, yang diperintahkan oleh Al Qur'an dan Sunnah, dan sedikit bagian penduduk yang kaya memperturutkan konsumsi menyolok, maka semakin tinggi toleransi masyarakat terhadap ketidakmerataan pendapatan dan kekayaan. Di lain pihak, semakin jelasnya deprivasi dipandang relative oleh sebagian penduduk sebagai hasil dari tidak terpenuhinya kebutuhan dasar dan konsumsi menyolok yang dilakukan oleh kaum kaya, maka semakin rendahlah toleransi masyarakat terhadap ketidakmerataan. Dengan memperlihatkan sepenuhnya kepedulian terhadap lesejahteraan para kaum miskin melalui pembrantasan kemiskinan absolute dan dengan memelihara ketidakmerataan pendapatan dan kekayaan dalam batas-batas yang dapat diterima, maka periode Islam yang pertama memberikan demostrasi yang praktis mengenai tatanan ekonomi kesejahteraaan keadilan syariah (Ahmad, $1998: 9)$. 


\section{F. Etika Bisnis dalam Islam: Solusi yang Berkeadilan}

Apakah dalam bisnis diperlukan etika atau moral? Jawabannya sangat diperlukan dalam rangka untuk melangsungkan bisnis secara teratur, terarah dan bermartabat. Bukanlah manusia adalah makhluk yang bermartabat?

Islam sebagai agama yang telah sempurna sudah barang tentu memberikan rambu-rambu dalam melakukan transaksi, istilah al-tijarah, al-bai'u, tadayantum dan isytara (Muhammad dan Lukman Fauroni, 2002: 29) yang disebutkan dalam al-Quran sebagai pertanda bahwa Islam memiliki perhatian yang serius tentang dunia usaha atau perdagangan. Dalam menjalankan usaha dagangnya tetap harus berada dalam rambu-rambu tersebut. Rasulullah Saw telah memberikan contoh yang dapat diteladani dalam berbisnis, misalnya:

1. Kejujuran.

Sesuatu yang dipercayakan kepada seseorang, baik harta, ilmu pengetahuan, dan hal-hal yang bersifat rahasia yang wajib diperlihara atau disampaikan kepada yang berhak menerima, harus disampaikan apa adanya tidak dikurangi atau ditambah-tambahi (Barmawie Umary, 1988: 44). Orang yang jujur adalah orang yang mengatakan sebenarnya, walaupun terasa pahit untuk disampaikan.

Sifat jujur atau dapat dipercaya merupakan sifat terpuji yang disenangi Allah, walaupun disadari sulit menemukan orang yang dapat dipercaya. Kejujuran adalah barang mahal. Lawan dari kejujuran adalah penipuan. Dalam dunia bisnis pada umumnya kadang sulit untuk mendapatkan kejujuran. Laporan yang dibuat oleh akuntan saja sering dibuat rangkap dua untuk mengelak dari pajak.

$$
\text { يأيها الذين امنوا اتقوا الله وكونوا مع الصادقين }
$$

"Hai orang-orang yang beriman, bertakwalah kepada Allah, dan hendaklah kamu bersama orang-orang yang jujur"

(Q.S. al-Taubah: 119)

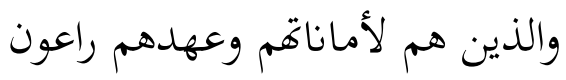

"Dan orang-orang yang memelihara amanat-amant (yang dipikulnya) dan janjinya" (Q.S. al-Mu'minun: 8)

Rasulullah Saw pada suatu hari melewati pasar, dimana dijual seonggok makanan. Beliau masukkan tangannya keonggokan itu, dan jari-jarinya menemukannya basah. Beliau bertanya: "Apakah ini hai penjual"? Dia berkata "Itu meletakannya di atas agar orang melihatnya? Siapa yang menipu kami, maka bukan dia kelompok kami" (Quraish Shihab, Ibid.: 8).

2. Keadilan

Islam sangat mengajurkan untuk berbuat adil dalam berbisnis, dan melarang berbuat curang atau berlaku dzalim. Rasulullah diutus Allah untuk membangun keadilan. Kecelakaan besar bagi orang yang berbuat curang, yaitu orangorang yang apabila menerima takaran dari orang lain meminta untuk dipenuhi, 
sementara kalau menakar atau menimbang untuk orang selalu dikurangi. Kecurangan dalam berbisnis pertanda kehancuran bisnis tersebut, karena kunci keberhasilan bisnis adalah kepercayaan. Al-Qur'an memerintahkan kepada kaum muslimin untuk menimbang dan mengukur dengan cara yang benar dan jangan sampai melakukan kecurangan dalam bentuk pengurangan takaran dan timbangan.

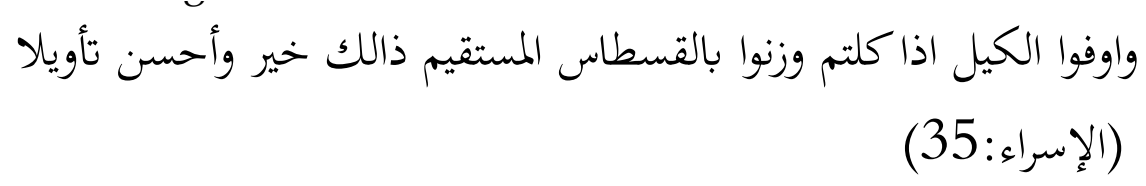

"Dan sempurnakanlah takaran apabila kamu menakar, dan timbanglah dengan neraca yang benar. Itulah yang lebih utama (bagimu) dan lebih baik akibatnya".

(Q.S. al-Isra': 35)

Dalam ayat lain yakni Q.S. al-Muthaffifin: 1-3 yang artinya:

"Kecelakaan besarlah bagi orang-orang yang curang (dalam menakar dan menimbang), yaitu orang-orang yang apabila menerima takaran dari orang lain mereka minta dipenuhi, dan apabila mereka menakar atau menimbang untuk orang lain, mereka mengurangi"

Dari ayat di atas jelas bahwa berbuat curang dalam berbisnis sangat dibenci oleh Allah, maka mereka termasuk orang-orang yang celaka (wail). Kata ini menggambarkan kesedihan, kecelakaan dan kenistaan. Berbisnis dengan cara yang curang menunjukkan suatu tindakan yang nista, dan hal ini menghilangkan nilai kemartabatan manusia yang luhur dan mulia. Dalam kenyataan hidup, orang yang semula dihormati dan dianggap sukses dalam berdagang, kemudian ia terpuruk dalam kehidupannya, karena dalam menjalankan bisnisnya penuh dengan kecurangan, ketidakadilan dan mendzalimi orang lain.

3. Barang atau produk yang dijual haruslah barang yang halal, baik dari segi dzatnya maupun cara mendapatkannya. Berbisnis dalam Islam boleh dengan siapapun dengan tidak melihat agama dan keyakinan dari mitra bisnisnya, karena ini persoalan mu'amalah dunyawiyah, yang penting barangnya halal. Halal dan haram adalah persoalan prinsipil. Memperdagangkan atau melakukan transaksi barang yang haram, misalnya alkohol, obat-obatan terlarang, dan barang yang gharar dilarang dalam Islam (Muhammad dan R.Lukman F, op.cit.: 136-138). Secara umum Islam menawarkan nilai-nilai dasar atau prinsip-prinsip umum yang penerapannya dalam bisnis disesuaikan dengan perkembangan zaman dan mempertimbangkan dimensi ruang dan waktu. Nilai-nilai dasar etika bisnis dalam Islam adalah tauhid, khilafah, ibadah, tazkiyah dan ihsan. Dari nilai dasar ini dapat diangkat ke prinsip umum tentang keadilan, kejujuran, keterbukaan (transparansi), kebersamaan, kebebasan, tanggungjawab dan akuntabilitas.

4. Tidak Ada Unsur Penipuan

Penipuan atau al-tadlis / al-ghabn sangat dibenci oleh Islam, karena hanya akan merugikan orang lain, dan sesungguhnya juga merugikan dirinya sendiri. Apabila seseorang menjual sesuatu barang, dikatakan bahwa barang tersebut kualitasnya sangat baik, kecacatan yang ada dalam barang disembunyikan, dengan maksud 
agar transaksi dapat berjalan lancar. Tetapi setelah terjadi transaksi, barang sudah pindah ke tangan pembeli, ternyata ada cacat dalam barang tersebut. Berbisnis yang mengandung penipuan sebagai titik awal kehancuran bisnis tersebut.

\section{Kesimpulan}

Sesungguhnya praktek kapitalisme di Amerika Serikatyang mengeksploitasi tenaga kerja dengan upah yang rendah adalah suatu tindakan yang tidak bermoral. Manusia harus dihargai sesuai dengan kualitas kerja, dan mereka harus diletakkan sebagai mitra perusahaan bahkan menjadi aset penting dari perusahaan. Manusia tidaklah tepat kalau diletakkan sebagai unsur terkecil dari keseluruhan proses produksi, sehingga mereka tidak dapat mengoptimalkan kemampuannya. Mereka hanya dapat bekerja sesuai dengan jobnya masing-masing tanpa mengetahui pekerjaan lain yang menjadi jaringan dari proses produksinyanya. Praktek semacam itu selain dikritik oleh Marxis dan non-Marxis, juga oleh ajaran Islam. Islam tidak membenarkan adanya kepemilihan individual yang mengakibatkan mereka menguasai kekayaan. Islam juga tidak membenarkan kepemilikan bersama, karena hal ini bertentangan dengan prinsip-prinsip keadilan. Orang yang bekerja keras lebih berhak membelanjakan kekayaan baik untuk dirinya sendiri maupun untuk orang lain. Mereka yang malas bekerja tidak akan mempunyai hak yang penuh atas harta benda orang lain, mereka hanya berhak untuk menerima derma, infak, sadaqah dan zakat. Kepemilikan harta benda mutlak hak Allah semata. Manusia hanya diberi wewenang untuk mengelola dan menikmati sesuai dengan aturanaturan Allah Swt.

Islam menawarkan etika bisnis yang berkeadilan dengan berlandaskan pada keteladanan Rasulullah Saw dalam berbisnis, baik pada waktu sebelum diangkat menjadi Rasul maupun setelah menjadi Rasul. Al-Qur'an memberikan nilai dasar dan prinsip-prinsip umum dalam melakukan bisnis.Mulai sekarang dan selanjutnya Islam sangat tepat dijadikan rujukan dalam berbisnis, karena didalamnya menjunjung tinggi prinsip kejujuran, keadilan, kehalalan dan tanggungjawab yang betumpu pada nilai-nilai tauhid.

Sebagai penutup, kaitannya dengan ekonomi Islam, penulis meyakini adanya ilmu ini sebagai sebuah ilmu yang mandiri dan berbeda dengan ilmu ekonomi sekuler. Ilmu ekonomi Islam sangat sarat dengan nilai-nilai dan etika sehingga apabila diterapkan akan membawa dampak yang positif bagi kehidupan manusia dalam kegiatan ekonominya. Penulis melihat bahwa ilmu ekonomi Islam telah mempunyai akar dalam khazanah keilmuan Islam (fiqih) yaitu apa yang kita sebut dengan fiqih muamalah yaitu fiqih yang mengatur interaksi antara sesama manusia dalam rangka memenuhi kebutuhannya.

\section{DAFTAR PUSTAKA}

Abdullah, Taufik (ed.),. 1982. Agama, Etos Kerja dan Perkembangan Ekonomi. Jakarta: LP3ES.

Ahmad, Mustaq. 2001. Etika Bisnis dalam Islam. Jakarta: Pustaka Al-Kautsar.

Al Attas, Naquib, The Concept of Education in Islam, (Kuala Lumpur: ISTAC, 1991) dalam Majalah Islamia, Tahun II No. 6/Juli-September 2005 
al Faruqi, Ismail Raji. Islamisasi Pengetahuan (terj).Bandung: Pustaka, 1995

Al-Qur'an dan Terjemahnya. 1985. Jakarta: Departemen Agama RI.

Arifin, Syamsul, et al. Spiritualisasi Islam dan Peradaban Masa Depan. Yogyakarta: Sipress, 1996

Azizy, A. Qodri. Membangun Fondasi Ekonomi Umat. Yogyakarta: Pustaka Pelajar, 2004

Deliarnov. Perkembangan Pemikiran Ekonomi (Edisi Revisi). Jakarta: PT Raja Grafindo Persada, 1997

Ebenstein, W. 1980. Todays Ism. New Jersey: Prentice Hall.

Ghulsyani, Dr. Mahdi. Filsafat Sains menurut al Qur'an (terj). Bandung: Mizan, 1994

Hermeneia Jurnal Kajian Islam Interdisipliner Vol. 2 No. 2 Juli-Desember 2003

http://abiaqsa.blogspot.com/2007/07/islamisasi-ilmu-pengetahuan.html diakses pada tanggal 27 Nopember 2010

http://islamlib.com/id/index_php?page=article\&id=639 diakses pada tanggal 27 Nopember 2010

http://islamlib.com/id/index.php?page==article\&id=605 diakses pada tanggal 27 Nopember 2010

http://media.isnet_org/islam/Pac/ CeoriPolitik.html diakses pada tanggal 27 Nopember 2010

http://media.isnet_org/islam/QuraishlWawasan/Politikl.html diakses pada tanggal 27 Nopember 2010

Kunio, Yoshihara. 1990. Kapitalisme Semu Asia Tenggara. Jakarta: LP3ES.

M. Zainuddin, Filsafat Ilmu Perspektif Pemikiran Islam. Malang: Bayumedia, 2003

Ma'arif, A. Syafi'i dan Said Tuhuleley, Al-Qur'an dan Tantangan Modernitas. Yogyakarta: Sipress, 1996. Cet. IV

Maryadi dan Syamsuddin (ed.),. 2001. Agama Spiritualisme dalam Dinamika Ekonomi Politik. Surakarta: Muhamamdiyah University Press.

Mubyarto dkk.1991. Etos Kerja dan Kohesi Sosial. Yogyakarta: Aditya Media.

Muhammad dan R.Lukman Faurani. 2002. Visi Al-Qur'an Tentang Etika dan Bisnis. Jakarta: Salemba Diniyah.

Peterson, Wallace C. 1997. "Capitalism”, dalam Internet Microsoft, Encarta 97 Encyclopedia 1993-1996.

Rahardjo, Dawam. 1995. "Etika Bisnis Menghadapi Globalisasi dalam PJP II", dalam Prisma, No. 2. Jakara: LP3ES.

Rahman, Afzalur. Doktrin Ekonomi Islam jilid I (terj). Yogyakarta: Dana Bhakti Wakaf, 1995

Richard T, De George. 1995. Business Ethics, Ed. 4. New Jersey: Printice Hall.

Shihab, Muhammad Q. 1997. “Etika Bisnis dalam Wawasan Al-Qur'an”, dalam 
Ulumul Qur'an, No.3/Tahun V.

Soleh, A. Khudori, Wacana Baru Filsafat Islam.Yogyakarta: Pustaka Pelajar, 2004 Sufyanto (Ed), Cita-Cita Islam. Yogyakarta: Pustaka Pelajar, 2000

Yuliadi, Imamuddin. Ekonomi Islam, Sebuah Pengantar. Yogyakarta: LPPI, 2001

Yusuf, Choirul F. 1997. "Etika Bisnis Islam: Sebuah Perspektif Lingkungan Global", dalam Ulumul Qur'an, No. 3/Tahun V. 